\title{
CURRENT STATE'S ATTITUDE TOWARDS MUNICIPAL SELF-GOVERNMENT IN SLOVAKIA
}

\author{
Martin Vernarský ${ }^{1}$
}

\begin{abstract}
The aim of the presented article is to point out, on the basis of a selected casuistry, signals indicating the attitude of the state (judicial power as part of the state power) towards the self-government in Slovakia. The author focuses only on the sphere of the municipal self-government because of its explicit constitutional embedding and also because of a limited extent of this article. It is about examination, whether the imaginary scissors between the legal regulation and putting it into practice open or close and from a broader perspective it is also about examination whether the statist attitude towards the role of the state in ensuring public law activities, in spite of changes in legal regulations after 1989, still remains or is gradually eliminated.
\end{abstract}

KEY WORDS: State, Municipal Self-Government, Legal Liability, Judicial Review.

\section{INTRODUCTION}

The attitude of the state towards municipal self-government (and towards self-government in general) is also the attitude towards decentralization of exercise of public power and the attitude towards application of the principle of subsidiarity in public administration. According to D. Beetham (2009, p. 289) the longer established democracies show wide variations between them and on the other hand, some recently established democracies shown relatively similar solutions on how to improve legitimacy of whole system. In this sense, the rising importance of local self-government units helps to get decision-making process closer to the citizens. Especially in postcommunist states which in vast majority have respected a requirement of continuity of a legal system even despite social changes, an actual form of the attitude towards self-government is a significant indicator of a democratic character of the state.

When examining the attitude of the state towards self-government, we believe that the most relevant approach is to arise from legally regulated

\footnotetext{
${ }^{1}$ Department of Public Law Disciplines, Faculty of Public Administration, Pavol Jozef Šafárik University in Košice, Popradska 66, 04001 Košice. E-mail: martin.vernarsky@upjs.sk
} 
attitudes of individual bodies of the state power towards the municipal self-government. From among them a legislative power is especially important, which, with respect to a reservation in the law [Art. 67 par. 2 and 3 of the Constitution of the Slovak Republic (hereinafter referred to as the "Constitution")] in affecting status of municipalities and higher territorial units, frames life of municipal self-government units in a significant way. Relations between the municipal authorities not only become the object of legal confrontations, but they stir the criticism from the side of the laic public (Žofčinová, 2018, p. 256). Competently expressed will of the legislator must be necessarily and fluently followed by a judicial power upon which to a considerable extent depends an element of reality in implementing plans of the legislator creating the acts regulating status of municipalities and higher territorial units. The attitude of municipal self-government towards the executive body of the state power (i.e. state administration) is of a totally different quality since in the extent of entrusted power municipal selfgovernment is equal with the state administration (Drgonec, 2015, p. 1052).

The title of this article automatically takes existence of the right to selfgovernment for granted, which by far does not have to suit every part of the opinion spectrum within juridical science. Even in the past Hoetzl (1937, s. 175) stated that "self-government depends on the action and thus it is not a law anymore. Since this action is performed within a scope stipulated by the law, it is given as a reflection here, that unions which come under public law and govern themselves should have a right to self-government." Moreover, governing itself, ergo self-government, may concern various spheres, from which the entity enjoying advantages from self-governing directly benefits (groundskeeping, maintenance of a local cemetery and local communications, etc.) and thus, whether it concerns a right of self-government or not, is not perceived as a burning issue. However, if a claim of any victim on the side of the entity for the benefit of which and towards which the self-government actualizes should be a consequence of self-governing, then it is necessary to qualify self-government as the right, because only the right to exercise self-government powers evoke, on the side of the recipient of their exercise, a corresponding obligation lying in the requirement to tolerate exercise of the right on the self-government on behalf of a common good. Even a legal regulation accomplished, on the level of comprehension of the right to selfgovernment compared with the First Republic period, a significant shift.

Local self-government units represent important part of public administration and society as well. Contemporary social reality should be characterized as multidimensional consequence of ongoing globalisation 
and integration processes. As it was mentioned by Mital' (2018, p. 97) actual development of local self-government units and public administration overall is composed of ambitions such as making public administration more transparent, providing public goods in adequate quality and quantity, improving professionalism of employees or accomplishing requirements declared by international documents and international treaties. Besides, when discussing reforms at the local level of public administration, a distinction needs to be made between reforming local self-government in political aspects and the administrative capacity to support (local) public governance (Kovač, 2015, p. 132). At the same time local self-government units should be perceived as a dominant actor in the context of governing public issues in the surrounding territory. As it was mentioned by Žárska (2013, p. 356) local self-government units play an important role in the context of actual development tendencies based on a real existing social reality as well as execution of power determined personal, institutional, executional, political and economic aspects. At the same time, we have to admit that the execution of competencies at the local level have to be perceived in the context of fiscal decentralization. Generally speaking, we might argue with V. Vybíhal $(2018$, p. 96) that local authorities are considered to be an important element in Europe, especially because an administration performance usually becomes more effective and beneficial for an inhabitant who has the right to participate in governance directly and influence public issues. Based on above mentioned, the examined issue should be analysed in the context of various aspects and should be characterized by its interdisciplinarity. However, our attention will be put on a legal aspect of the examined issue, which we believe is the most relevant in our opinion.

For instance, pursuant to the Article 127a par. 1 of the Constitution (not accidentally but systematically following the Article 127 par. 1 of the Constitution providing a specific legal protection to entities whose fundamental rights and freedoms have been violated) a municipal selfgovernment body may complain against unconstitutional or unlawful decision or any other unconstitutional or unlawful action concerning the matters of municipal self-government. Even though in a formulation of this power a terminology "right to self-government" is not used, if such rightwould not have existed and constitution makers would not have acknowledged it, then they could have hardly grant it a specific legal protection before the independent judicial body protecting the constitutionality. Moreover, pursuant to the Article 127a par. 2 of the Constitution, if the Constitutional 
Court meets the complaint, it voids a challenged decision, or if a violation of the right concerned other interference than the decision, the Court shall prohibit violation of the right and order, if possible, to restore a status before the violation. Even in the case that we have understood a term "right" used in this provision objectively, last remnants of doubt are eliminated by the $\S 58 \mathrm{~d}$ par. 2 of the Act of the National Council of the Slovak Republic No. 38/1993 Coll. on organization of the Constitutional Court of the Slovak Republic, on proceedings before it and on the status of its judges as amended by later regulations, which in procedural regulation of the proceedings according to the Article 127a of the Constitution states that if a violation of the right to municipal self-government concerned other interference than the decision, the Constitutional Court shall prohibit violation of the right and order, if possible, to restore a status before the violation. So this formulation explicitly mentions "right to municipal self-government", whose content should be undoubtedly identified in connection with the fact that protection in proceedings on so-called municipal complaints is provided in the "matters of municipal self-government". Concept of the Article 127a of the Constitution in connection with a legal regulation, therefore serves as a proof that self-government has its expression in a subjective right of its bearer.

Therefore, we can conclude that a normative legal regulation, whose transfer into a real life is a responsibility of the judicial power, takes into account a right to self-government. This substantiates a following examination of the quality of implementation power activity of public administration bodies whose responsibility is to implement a legislative will into everyday practice.

\section{CHARACTER OF THE MUNICIPAL COMPETENCY}

The Supreme Court of the Slovak Republic (hereinafter referred to as "the Supreme Court") in proceedings on a negative competency conflict between the public administration body and the court expressed in the decision from 10th October 2011 ref. no. 5 Rks 2/2011 a legal opinion, according to which in decision-making process of the municipality in vindicatory matters, it must always be a delegated performance of state administration. It referred to a systematic and logic interpretation of the $\S 2$ of the Act no. 416/2001 Coll. on transfer of certain competencies from state administration bodies to municipalities and higher territorial units as amended by later regulations (hereinafter referred to as the "Act No. 416/2001 Coll."), as well as to purpose 
of the Act. However, it did not explain this interpretation any closer. The mentioned provision only enumerates competencies which according to the legislator's will were transferred to municipalities. The legislator (with few exceptions) has not stipulated whether enumerated competencies were transferred to a system of delegated state administration or to a sphere of municipal own competencies. Moreover, this provision has not concerned the competency, which was the matter in the judged negative competency conflict, at all. It is also necessary to mention that at that time (at the time of committing the administrative delict which led to the competency conflict and also at the time of the decision-making by the Court) the $\S 4$ par. 4 of the Act of the Slovak National Council No. 369/1990 Coll. on municipal establishment as amended by later regulations (hereinafter referred to as the "Act on municipal establishment") has been effective, according to which, if the law in amendment of the competency of the municipality does not stipulate that it is a performance of delegated competencies of the state administration, it applies that it is a performance of municipal selfgovernment competency. A similar interpretation rule has been stipulated by the legislator also in the $\S 4$ par. 2 of the Act No. 416/2001 Coll. The matter in controversy concerned imposing of the fine according to the $\S 13$ par. 9 letter b) of the Act on municipal establishment ${ }^{2}$ which does not state that it concerns a performance of delegated state administration.

Later in substantiation of its decision the Supreme Court stated that general subordination of the competency in controversy under the system of delegated state administration requires equality of the parties to the proceedings with respect to the $\S 83$ par. 2 of the Act of the Slovak National Council No. 372/1990 Coll. on misdemeanours (hereinafter referred to as the "Act on misdemeanours"), according to which a bill of review by the Court regarding the decision on misdemeanour may be submitted after exhaustion of legitimate remedy in the administrative proceeding. In opinion of the Supreme Court there was no reason to obstruct the review of the decision according to the $\S 13$ par. 9 letter b) of the Act on municipal establishment, i.e. decision on administrative delict different from the misdemeanour, in a due appeal procedure in the administrative proceeding.

However, in our opinion, the Supreme Court did not take into account that the mentioned provision of the Act on misdemeanours became effective as

\footnotetext{
${ }^{2}$ A mayor may impose a fine in the amount up to 6,638 EUR on a legal or natural person authorized to conduct business if they do not keep the property or real estate clean and tidy and thus they disrupt the appearance or environment of the municipality or if they contaminate a public space or dump things outside designated areas.
} 
of 1st October 1990, i.e. at the time when judicial review of administrative decisions has not been built on the principle of general clause yet. At that time the administrative jurisdiction, in a form required by the principle of legal state, de facto, nor de iure, has not existed yet ${ }^{3}$. Therefore, the problematic and frequently criticized legal regulation regarding decisionmaking about remedies against unlawful decisions of administrative bodies, which according to the $\S 27$, par. 2 of the Act on municipal establishment should have been applied also in the case of appeal against the decision of the mayor of the municipality in the reviewed case, has not been effective as well.

In our opinion, under circumstances described above, the Supreme Court unreasonably has not respected the will of the legislator. Its content is focused on emphasizing importance of self-government through the interpretation rule embedded in the $\S 4$, par. 4 of the Act on municipal establishment. This legal norm is not only of a formal character which serves in assessment of the actual authority assigned to the municipality by the law with respect to the fact, whether it is a delegated state administration or performance of municipality's own authority. It conceals also a value message for bodies implementing the law (acts), from which it follows that they are obliged to examine the attitude of the legislator towards fulfilment of a specific duty assigned to the municipality. Only in case, when the legislator explicitly mentions in the act that it concerns a delegated state administration, it is possible to come to a conclusion, about such substantial nature of the impact of performance of the relevant competency on the interests protected by the law, that the state has decided to take responsibility for its due and proper performance. In other cases the court or another body of public authority must arise from the constitutional nature of the municipal self-government as well as from a democratic character of the state which is in regarded circumstances characterized by asserting the principle of subsidiarity and decentralization associated with it.

\section{LIABILITY OF THE MUNICIPALITY IN ASSET MANAGEMENT}

Another sphere of cases indicating a problematic attitude of the state power towards municipal self-government are situations when the state

\footnotetext{
${ }^{3}$ According to $\S 244$ of the Civil Code effective at that time, if the court according to the law is supposed to review decisions of other bodies, in such proceedings provisions of this Act shall be applied, unless a specific regulation does not stipulate otherwise. Therefore, it is evident that the legal regulation came from a need for explicit legal support regarding judicial review of a specified decision of the public administration body.
} 
groundlessly provides protection to legitimate interests of the municipality at the expense of another (private-law) entity being in a substantive-law relationship with the municipality.

In the proceeding registered under ref. no. III. ÚS 389/08 the Constitutional Court of the Slovak Republic (hereinafter referred to as "the Constitutional Court") acted in a complaint of a legal person - businessman, who demanded a judicial protection of the claim against the municipality which was allegedly a result of contractual relationship (contract of attorney in asserting restitution claims of the municipality). General courts (including the Supreme Court as the court of appeal) dismissed a lawsuit of the claimer because they came to a conclusion that the contract concluded with the municipality is absolutely void since the municipal council did not give the mayor an approval for its conclusion. Thus a question, whether the mayor needed approval of the municipal council to conclude the reviewed contract, became the subject matter of the dispute. Because according to a legal regulation effective at that time the reviewed contract did not belong to a sphere of legal acts which ex lege required approval from the municipal council. However, the relevant legal provision gave the municipal council authority to approve the document - principles of municipal asset management, in which the municipality could have determined also other legal acts in which, outside the requirement of the legislator, approval by the municipal council would be required. However, the council in the municipality which has been a party to the dispute did not approve such document. Under such circumstances the parties to the dispute had different opinions regarding whether the reviewed contract should have been a subject to approval by the municipal council or not. The Constitutional Court did not accept the complaint, when it stated that "the assets of the municipality, as assets of a public corporation serving mainly for performance of its duties given by the competencies in exercise of self-government, which are executed for the benefit of individual legal entities having a legally relevant relation to the municipal territory, may not be compared with assets of other private legal entities from a perspective of a legal system regarding manipulation with it. A need for a different legal system is given by the effort to guide use of municipal assets towards performance of duties of public character, to protect municipal assets from its misuse and from inefficient manipulation and to provide the most effective increase in value and development and thus, to a largest possible extent, prevent a situation characterized by the incapability of the municipality to fulfil its public functions duly and on time due to insufficient asset base." Subsequently, from such concept the Constitutional Court came 
to a conclusion that "provision of the $\S 9$ par. 2 letter b) a c) of the Act on municipal assets should be interpreted in a narrowing way when it comes to authority of the mayor to execute legal acts in matters of movable assets of the municipality or its property rights in case that such manipulation is not restricted by the law or by the municipality itself through the binding act of the municipal council. In this context it is necessary to approach the extensive interpretation of the provision $\$ 11$ par. 4 letter a) of the Act on municipal establishment which grants the municipal council a right to approve the most important laws concerning municipal assets. Extensive interpretation lies in the fact, that disapproval of the principles regarding management and manipulation with the municipal assets by the municipal council does not deny this body of municipal self-government a right to bindingly give opinions on the most important laws regarding the municipal assets." In this connection the Constitutional Court referred to a sum of almost 8 million SKK which the municipality would have been obliged to pay the claimer if the Court came to a conclusion that the mayor of the municipality was entitled to sign the respective contract even without the approval of the municipal council. Thus specified amount according to the Constitutional Court put signing of the disputed contract into the category of the most important property-law acts of the municipality.

Municipal self-government consists also in liability of its bearer for the way how they use delegated power. In the property sphere the extent of municipal self-government is determined by the state and the law and in the Slovak Republic handling with movable assets and with property rights is left almost exclusively to the scope of power of municipal bodies. Then the liability of the municipality is manifested also in seizing all opportunities given to the municipality by the regulations, so that the municipal council could give opinions on the most important legal acts. These opportunities include a very important one, approving principles of municipal asset management. Even though legal regulations have not stipulated any sanctions for disapproval of the document, it is necessary to emphasize that it refers to the absence of sanctions in public sphere. It is correct that this way the state does not impose sanctions on municipalities without approved principles of asset management. Because the municipalities have to realize that it is in their own interest to stipulate more specifically decision-making concerning property law acts. Only when they come to such realization, a fundamental condition for real self-government character of performance of their duties in the property area is met. And if a respective municipality shall not approve principles of municipal asset management, it is not creating a 
wider basis for effective, functional and in the broadest sense of the word economical manipulation with its assets. Then, individual property-law acts of the municipality shall be decided to the full extent only by one person, i.e. the mayor of the municipality as the statutory body of the municipality in the property-law relationships. This may carry very notable property consequences.

However, in the analyzed case the state through its judicial bodies has provided protection to the property interest of the municipality, whose representatives did not seize the opportunity given to them by the law and did not specified principles of municipal asset management. Thereby they allowed the mayor of the municipality to decide on manipulation with the municipal assets without their involvement, which the mayor did. At the moment when consequences of failing to bear responsibility of the municipality for managing its own assets have manifested in a form of a legal action, the state protected the asset base of the municipality by applying interpretation which does not respect such extent of independence of the municipality in managing its own assets as stipulated by legal regulations. Thus the state has not interfered with the independent sphere of municipal powers on the basis of the law, but beyond its bounds, because interpretation of the legal regulation in this case did not conform to the Constitutional concept of the status of municipal asset (quoted Art. 65 par. 1 and Art. 67 par. 3 of the Constitution).

In the case which we referred to they managed to prevent reduction of the asset base of the municipality by considerable financial amount, however, conceptually and perspectively the attitude of the judicial bodies is not acceptable. Because it demonstrates a protective attitude of the state towards municipalities also in those areas, in which the municipality independently, even though bound only by the law, performs its scope of powers. Eventually, municipalities actually lose its independence. The right decision would be to open a way for holding a municipality liable for the fact that by disapproval of principles of asset management it established its own conditions for decision-making regarding manipulation with its assets in compliance with the law. And all that even at the cost of serious financial trouble into which the municipality could get. There is no doubt that in the case concerning the legal person, i.e. private law, acting courts would not be interested in autonomous distribution of decision-making mechanisms of the legal person (unless they are prescribed by law), but they would examine compliance of this legal person's will with the law. However, in relation to the mentioned municipality, with their interpretation of the 
legal text, they filled in a blank space in normative regulation concerning manipulation with municipal assets, which occurred because of disapproval of principles regarding asset management. Such legal status is not in contradiction with the law and it is a matter of independent decision of the municipality whether it shall fill in the mentioned blank space or not. The state through the judicial bodies is not entitled to interfere with this independent decision-making sphere of the municipality, failing which it does not respect self-restraint embedded in the Constitution and also in the Act on municipal establishment.

\section{LAW-MAKING OF MUNICIPALITIES IN A SPHERE OF REGULATION OF GAMBLING}

Tradition of competencies within a sphere of gambling operation under conditions on today's territory of the Slovak Republic has started to be built after 1989, when the Act of the National Council of the Slovak Republic No. $194 / 1990$ Coll. on lotteries and other similar games (effective as of $18^{\text {th }}$ May 1990 ) entitled in its $\S 18$ par. 1 letter a) former local committees to issue on their territory individual permissions for operation of slot machines. In November 1990 the Act on municipal establishment became effective and competencies of local committees were transferred to municipalities. Since effectiveness of the Act No. 171/2005 Coll. on gambling games and on amendments to certain acts (hereinafter referred to as "the Gambling Act “) decision-making practice of municipalities in matters of gambling licensing has been gradually built. The respective individual decision-making power has been left to municipalities also after May $1^{\text {st }} 2005$ when the Gambling Act became effective and it is effective until now. The Gambling Act has not regarded municipalities or their bodies as bodies of the state administration in the area of gambling (see $\S 10$ par. 1 of the Gambling Act), but it has granted them a competency to exercise supervision regarding observance of this Act, other generally binding legal regulations and conditions specified in the individual licence issued according to this Act by the municipality, to manage levies into municipality budget as well as to decide on granting individual licences, if stipulated by the law ( $§ 10$ par. 5 of the Gambling Act effective as of $31^{\text {st }}$ August 2011).

Competencies of municipalities were subsequently going through partial corrections but a radical change came with the amendment to the Gambling Act executed by the Act No. 228/2011 Coll., which changes and amends the Act No. 171/2005 Coll. on gambling and on amendment to certain acts 
as amended by later regulations and which has extended a portfolio of municipal powers in the area of gambling operations with the law-making authority.

It is useful to state that this change does not represent any kind of a cosmetic change of accepted and by law regulated concept of administration in a sphere of gambling operations. The position of the municipality on the level of individual decision-making authority (granting certain types of individual licences) is governed by totally different principles in comparison with the authority to regulate social relationships in a generally binding way. The municipality, by obtaining law-making power regarding gambling, has become an entity entitled to infringe a fundamental right to conduct business, from which other independent quality demands regarding this power activity arise.

The explanatory report to a representative proposal on change and supplement of the respective amendment submitted to the National Council of the Slovak Republic (hereinafter referred as "the National Council) does not contain any really reliable analyses or any other substantiations showing readiness of municipal self-government system in Slovakia to perform a respective competency. However, from a stenographic record of debates in the assembly of the National Council it is possible to identify that intention of proposers of the respective amendment has been "a higher participation in decision-making process for self-governments and thus also for people living in that environment. That means, not for self-governments without any real purpose, but for self-governments as representatives of people who are directly affected, who want to have a chance to decide on how their living environment, the place where they live, where their children go to school, where they work, where they simply implement their own ideas of happiness, should look like." (www.nrsr.sk, 2011).

The analyzed amendment to the Gambling Act has become effective as of $1^{\text {st }}$ September 2011. But on $28^{\text {th }}$ September 2012 the Government of the Slovak Republic (hereinafter referred to as "the Government") approved a proposal for another revision of the Gambling Act according to which acceptance of generally binding regulation of the municipality on regulation of gambling on its territory should have been conditioned upon a finding that operating of gambling games violates a public order while such finding

\footnotetext{
${ }^{4}$ It concerned substantiation of one of the proposers of the amendment which was subsequently changed and amended by the proposed amendment of another representative containing a new version of the $\S 10$ par. 5 letter d) of the Gambling Act in a form which has been later a subject to review by the Constitution Court.
} 
must have been authorized by a decision of municipal population in a local referendum. The Government argued mainly with the opinion of the General Prosecutors Office of the Slovak Republic (hereinafter referred to as the "General Prosecutors Office") submitted within interdepartmental consultation (https://lt.justice.gov.sk, 2012), according to which generally binding regulation as a legal enactment not having a legal and lawful power may not infringe fundamental rights and freedoms, including the right to conduct business ${ }^{5}$. A government proposal regarding amendment to the Gambling Act is, in our opinion not very wisely, based on a ragged institute of a local referendum (problem of its binding character), which moreover, according to the Act on municipal establishment in order to be valid, requires participation of at least half of qualified electors while the decision is accepted by an absolute majority of valid votes of participants in a local referendum, ( $§ 11 \mathrm{a}$ par. 8 of the Act on municipal establishment). Furthermore, in connection to the opinion of the General Prosecutors Office, it is important to add that the decision of the Constitutional Court from $16^{\text {th }}$ June 1998 which was referred to in the comment, was issued in the proceeding on compliance of generally binding regulation with the Constitution (here the Constitutional Court actually expressed that its role in this proceeding was to find out whether municipal (local) council "by acceptance of generally binding regulation has infringed fundamental rights guaranteed by the Constitution"), not in a proceeding on compliance of the Act with the Constitution. In this decision the Constitutional Court has expressed non-compliance of the reviewed generally binding regulation with the Constitution because "a legal system infringing a right to conduct business guaranteed in the Art. 35 par. 1 of the Constitution has not been stipulated by the law, but by the generally binding regulation". Therefore, the Constitutional Court was examining whether the municipality (city district) had a necessary legal basis for acceptance of the respective generally binding regulation and it did not find fulfilment of this condition ${ }^{6}$. A legal control of generally binding regulations within a sphere of gambling control does not show described attributes, because the legislator explicitly provided

\footnotetext{
${ }^{5}$ The General Prosecutors Office referred to a finding of the Constitutional Court ref. no. II. ÚS 70/97 dated $16^{\text {th }}$ June 1998 (published in the Collection of Laws of the Slovak Republic, under No. 201/1998 Coll.), according to which "acceptance of generally binding regulation infringing the right to conduct business is not a part of law-making authority of the municipality. The right to conduct business is pursuant to the Constitution of the Slovak Republic guaranteed with a stricter protection because a Constitution maker allowed only the National Council of the Slovak Republic to amend conditions of exercising this right in a form of the act."

${ }^{6}$ However, it stated that until $1^{\text {st }}$ July 1994 such legal basis in the trade law existed.
} 
municipalities with a legal basis for such control. Therefore, in our opinion, the arguments leading the Constitutional Court to the decision ref. no. II. ÚS $70 / 97$ were not applicable in the case of a legal construction included in the Gambling Act.

However, during negotiations on a respective government proposal regarding the amendment to the Gambling Act (also in connection with heated debates in the parliament assembly) amendment proposal from the member of the parliament has been approved, which has modified a government condition for acceptance of the generally binding regulation to such extent that instead of a local referendum a petition of at least $30 \%$ of population in the municipality of age 18 years and older, in which they complain that a public order in the municipality is violated in connection with gambling, is sufficient. This amendment proposal has been substantiated relatively laconically and without more detailed analyses; the only reason can be identified in connection with a required quorum of petitioners ${ }^{7}$.

In 2015 a group of members of the National Council tried to amend the regulation concept described above with a proposal for change of the Gambling Act (www.nrsr.sk, 2015), but in the first reading the National Council decided not to continue in negotiations regarding this proposal ${ }^{8}$.

\footnotetext{
${ }^{7}$ Specifically it states that "existing application of law showed that it is necessary to stipulate also conditions under which the municipality may exercise this legal competency. It is proposed that such condition should be a complaint of municipality inhabitants submitted in a form of petition. Regarding the fact that it concerns matters of common interest of the municipality inhabitants it appears that the most relevant would be for inhabitants of the municipality to give opinions themselves on violation of a public order, if they perceive gambling as unbearable worsening in quality of life in the municipality. In civil society it is common to use petition in order to give opinion on serious problems of municipal life. When it comes to a proposed quorum, a 30\% requirement may be considered as optimum. The same quorum is used in the Act on municipal establishment in case of dismissal of the mayor or announcement of a local referendum. Petition as opposed to referendum seems to be more flexible, accessible to inhabitants and for this reason also more convenient."

${ }^{8}$ It is worth mentioning that the General Prosecutor has not challenged a legal regulation of the Gambling Act effective since $1^{\text {st }}$ January 2013 with a proposal to review its compliance with the Constitution even though from a position of reservations from the General Prosecutors Office formulated in already mentioned opinion no change has been made, since eventually, from the $1^{\text {st }}$ January 2013 conditions regarding gambling operations were stipulated in a binding manner by the municipality still in a form of generally binding regulation, which according to the opinion of the General Prosecutors Office is unconstitutional.
} 


\subsection{Review of the Constitutional Court in the matter of ref. no. PL. ÚS $4 / 2016$ and its analysis}

After the amendment executed by the Act No. 439/2012 Coll. of the Gambling Act became effective ( $1^{\text {st }}$ Jan 2013) and after failure of the attempt to amend the legal regulation, a proposal of a group of members of the National Council was delivered to the Constitutional Court on $18^{\text {th }}$ January 2016 to express non-compliance of the $\S 10$ par. 5 letter d) in a wording "under conditions according to the paragraph 6" and $\S 10$ par. 6 first sentence of the Gambling Act with the Art. 1, Art. 27 par. 1, Art. 64, Art. 64a, Art. 67 par. 1 first sentence and par. 3, Art. 68 of the Constitution, as well as the Art. 3 par. 1 and 2 first sentence, Art. 4 par. 2 and 4 of the European Charter of Local Self-Government ${ }^{9}$. The point of the proposal was to criticise the concept for regulating law-making authority of municipalities in the area of gambling operations, since conditioning of its performance was perceived by proposers as unconstitutional interference with the constitutional right of municipalities to self-government.

A concept established by the legal regulation, which is a subject to review executed by the Constitutional Court, is based on the combination of direct democracy element (petition supported by a given number of municipal population) and indirect democracy element (acceptance of generally binding regulation by the Municipal Council). In approval procedure regarding the stated construct in the National Council, doubts about constitutional acceptability occurred during a discussion about the relevant amendment of the Gambling Act, however, they were only marginal and they remained basically unnoticed. Their point aimed more at (non)compliance with a representative mandate of a member of the municipal council, than at unlawful violation of the right to self-government.

The Constitutional Court refused a proposal from the group of members of the National Council with a finding PL. ÚS 4/2016-125 dated 10 ${ }^{\text {th }}$ May $2017^{10}$.

In substantiation of the finding the Constitutional Court expressly stabilized deducibility of the right to self-government from constitutional norms. In its opinion "a right to self-government is not expressly formulated by the Constitution, ... however, from the Art. 64 and Art. 64a ("independent... self-

\footnotetext{
${ }^{9}$ Proposers disputed also noncompliance of another part of the $\S 10$ par. 5 letter. d) of the Gambling Act, however from a perspective of the scope of our article it is marginal; moreover in this part the Constitutional Court dismissed the procedure after amendment of the said part of the $\S 10$ par. 5 letter d) of the Gambling Act.

${ }^{10}$ The proceeding has been partially dismissed; however from a perspective of this article's scope of interest it is not necessary to pay attention to this part.
} 
government") of the Constitution in connection with a democratic character of the Slovak Republic arising from the Art. 1 par. 1 of the Constitution, it is deducible. The right to self-government as a collective right belongs to a local community (Art. 64a of the Constitution -"associating persons having a permanent residence in their territory"), municipality and higher territorial unit, to which the Constitution-maker grants legal subjectivity (Art. 65 par. 1 of the Constitution). Inseparable part of the right to self-government belonging to the municipality as the entity institutionalized into a form of legal person under the public law, is performance of its own (original) competencies which are formed by decentralization of the state power. The municipality performs them in matters of municipal (local) significance on the basis of relative independence from the state. Their own competencies are performed by the elected bodies of the municipality on behalf and at liability of the municipality. This performance is in a regulation matter according to the Art. 64a of the Constitution supplemented with a personnel base ("associating persons with a permanent residence in their territory") and territorial base ("are... territorial... units"), which frame the right of the municipality to selfgovernment on implementation level." (item 76 of finding substantiation).

Thereafter the Constitutional Court formulated substantial legal conclusions according to which "the impugned legal regulation regulates municipal matters (limiting gambling operation in the municipal territory) only indirectly or mediately. The municipal council does not need an approval of another holder of the public power or body exercising a public power on behalf and at liability of the public power entity other than the municipality, for acceptance of generally binding regulation controlling gambling operation in a respective municipality. Only after fulfilment of this condition it would be possible to consider a constitutionally relevant interference with the right of the municipality to self-government because performance of the municipal selfgovernment would be conditioned upon the manifestation of will of the entity which shall eventually not be held liable for a result of exercising municipal self-government power." (item 8 of finding substantiation). Subsequently the Constitutional Court concluded that "authority of the particular municipal council to normatively regulate gambling operation in the territory of the municipality is not conditioned upon permission, consent or any other legally significant act of another bearer of public power (state, self-governing region or their bodies). On the contrary, conditio sine qua non for acceptance of generally binding regulation regulating gambling operation is represented by manifestation of will (petition) of $30 \%$ of municipal population, i.e. those subjects which are associated in the municipality as in self-governing unit (Art. 
$64 a$ of the Constitution in connection with $\S 3$ par. 1 of the Act on municipal establishment) and on behalf of which the municipal self-government should be implemented." (item 83 of finding substantiation).

In our opinion the argumentation line applied by the Constitutional Court is not set correctly. It is based on the foundation according to which acceptance of generally binding provision pursuant to the Gambling Act limits a qualified manifestation of will of $30 \%$ of municipal population. As if, the Constitutional Court has shifted its argumentation to a level of implementation of law under conditions of particular municipality. But it omitted the fact that described condition for exercising the law-making authority of the municipality in a gambling sphere, is established by the legislator, i.e. state authority, and if the municipality wants to limit gambling operation in its territory, it must meet the condition prescribed by the legislator.

We may not accept a conclusion according to which conditioning of lawmaking authority of the municipal council upon the petition of municipal population does not present infringement of the municipal right to selfgovernment. Infringement of the fundamental right is when the procedure of the state denies or prevents the holder of the fundamental right in its asserting to the largest possible extent (Barak, 2012, 102). In the analyzed case the Constitutional Court admitted the existence of the constitutional right of the municipalities to self-government as well as the fact that law-making is, from a perspective of regulation included in the Article 68 of the Constitution, an integral part of the constitutional right of the municipalities to self-government ${ }^{11}$. Therefore, in our opinion, there is no doubt that compared to the law-making in other cases, in generally binding regulation of gambling operation the municipality has a hampered position because in order to accept the respective generally binding provision it must meet a condition (obligation) which in cases of other generally binding regulations is missing. And this condition has been prescribed to the municipality by the state ${ }^{12}$, not by inhabitants of the municipality as

\footnotetext{
${ }^{11}$ In the item 77 of substantiation for the finding the Constitutional Court literally states that "law-making is a significant and constitutionally anticipated component of performance of municipality's own competencies (Article 68 of the Constitution), i.e. the authority to regulate social relationships which come under the sphere of municipality's own matters in a generally binding manner.".

${ }^{12}$ However, a literature cited very aptly by the Constitutional Court in the Article 81 of the finding substantiation ["Municipal self-government is infringed by each regulation of municipal matters whose originator is a bearer of the public power other than the municipality (Jarass, $H$., Pieroth,B. Grundgesetz für die Bundesrepublik Deutschland. Kommentar. 2. Auflage. München: C. H. Beck, 1992, s. 432).'] is from a perspective of the formulated condition for a conclusion
} 
the Constitutional Court is trying to suggest in its argumentation ${ }^{13}$. Only the generally binding regulation of the municipality has a binding impact on a form of gambling operation in the territory of the municipality. Quite naturally it is not a petition of $30 \%$ of municipality population. And in order to assert the law-making authority which is a part of the right to self-government and to regulate gambling operations on its own territory as they wish, the municipality must organize a petition in which at least $30 \%$ of its population must complain that in connection with the gambling operation there is violation of the public order. A serious consequence of a meritorious legal conclusion of the Constitutional Court speaks also in favour of the formulated conclusion. If the National Council would approve the amendment to the Gambling Act in few months according to which a previous petition of not $30 \%$ but $95 \%$ of the municipality population would be necessary for acceptance of legally binding regulation regarding gambling operation, then the Constitutional Court (if it has respected a requirement of consistence of their own opinions) in case of review of constitutionality of such legal regulation would had to resign again with pointing out the fact that the construct in question "represents... enforced authenticity of "selfgoverning" of a local community and group of natural persons according to the $\S 10$ par. 6 of the Gambling Act is an integral part of it. From a perspective of constitutional categorization it is then enforcement of a direct democracy by integrating a petition form of municipal self-government performance into the legal regulation" (item 85 in the finding substantiation). However, admitting such conclusion or result means admitting a total amputation of law-making ability of the municipality, as a relative power sovereign on its own territory, to act. Acceptance of thinking this way may in future lead to very undesirable interferences from the legislator into the right of the municipality to self-government. We can say that legal conclusions of the Constitutional Court in the matter PL. ÚS 4/2016 directly encourage the legislator to other restrictions of municipality law-making also in other control spheres, hidden behind enforcement of authenticity of municipality performance and enforcement of mutual bonds between municipality population and its elected bodies.

that there is infringement of the right to self-government in the reviewed case, fulfilled.

${ }^{13}$ In the item 83 of the substantiation it clearly indicates that "conditio sine qua non for acceptance of the generally binning regulation controlling gambling operation represents a manifestation of the will (petition) of 30\% of municipal population, ergo those subjects which are associated in the municipality as a self-government unit (Art. 64a of the Constitution in connection with $\S 3$ par. 1 of the Act on municipal establishment) and on behalf of which the municipal self-government should be executed." 


\subsection{Alternative to legal opinions and conclusions of the Constitutional Court}

In order not only to criticize legal opinions of the Constitutional Court it is appropriate to present also alternative approach to review of disputable provisions of the Gambling Act from a perspective of their compliance with the Constitution.

In the first place we are aware that previous passages of this article may evoke the impression of uncritical defence of municipality independence in Slovak conditions together with effort to maximally narrow a room for the legislator to control matters regarding the territorial (municipal) self-government. We do not identify ourselves with such attitude. There is no doubt that even though a right of municipalities to self-government is a constitutional right, it may not be compared with fundamental rights included in the second chapter of the Constitution, in all attributes. It is given by a special character of this right since in its implementation it "tips over" to a form of exercise of public authority addressed to natural persons and legal persons in the municipality territory. Thus the municipality on one side exercises its right guaranteed by the Constitution, however, during this activity it may attack fundamental rights and freedoms of addressee of this performance. It is difficult to seek in this respect a parallel with other fundamental rights which during their implementation are not associated with exercise of public power from the side of their holder. The point of this article is not to analyze the right to self-government from a perspective of constitutional dogmatics. We presented this brief discursion in order to emphasize our own opinion regarding the large extent of space given to the legislator in order to control status and activities of municipal self-government. That is why a really legal regulation which conditions implementation of law-making form of municipal self-government upon manifestation of will of municipality population (whom legal consequences of normative control shall concern), at first sight does not seem so problematic on a level of potential conflict with a collective right of the municipality to self-government.

In our opinion, from a perspective of potential escalating of strictness regarding this condition from the side of the legislator, the Constitutional Court should have kept an option to protect municipalities in their constitutional-law perspective against other potential and more intensive attacks from the side of the state power. 
Actual development of constitutional-law views on Slovak municipal self-government leads into two fundamental and sufficiently tangible requirements which must be (evidently accumulatively) met in order to say that particular interference of the state respects the right of the municipality to self-government on its constitutional-law level.

The first, formal requirement arises from the Constitution itself, according to which obligations and limitations in exercising territorial selfgovernment may be imposed to the municipality by the law and on the basis of international contract according to the Art. 7 par. 5 (Art. 67 par. 2 of the Constitution) and the state may interfere with the activity of the municipality only in a manner stipulated by the law (Art. 67 par. 3 of the Constitution). In the reviewed matter this condition has been evidently met.

The second, material requirement arises from the premise according to which the constitutional principle of municipal self-government which is one of the fundamental values of democratic and legal state (Art. 1 of the Constitution) must be constitutionally protected independently from a legal regulation. Thus the constitutional definition of a term "municipal self-government" can't depend only on the legal regulation, because that could eventually lead to arbitrariness of the legislator and to violation of the principle of "municipal self-government" in its essence which is one of the fundamental democratic values of "democratic and legal state" and which therefore, as the constitutional principle, must be constitutionally protected independently from the legal regulation (I. ÚS 55/00).

Reviewing of fulfillment of the second defined condition, which in our opinion the Constitutional Court should have commenced, would be a matter of evaluation of proportionality regarding infringement of the right of the municipality to self-government. The proportionality test standardly reviews constitutionality of public power interferences with the fundamental rights and freedoms of natural and legal persons. Since the Constitutional Court has already stabilized the character of the right of the municipality to self-government, comparable with the catalogue of fundamental rights and freedoms according to the second chapter of the Constitution, the proportionality test would represent an applicable methodical approach also in the matter of PL. ÚS 4/2016 ${ }^{14}$. From a constitutional perspective it is

\footnotetext{
${ }^{14}$ In our opinion in the reviewed matter a legal opinion of the Federal Constitutional Court could be an appropriate methodological approach to the problem, according to which a key content (Kernbereich) of the right to self-government would be certainly violated if municipal self-government shall be completely eliminated or emptied in such way that the municipality shall not have a sufficient space for fulfilment of municipality's duties (e.g. decision from $7^{\text {th }}$ October 1980 in related matters ref. no. 2 BvR 584, 598, 599, a 604/76). However, not each
} 
essential that the limit implemented by the legislator de facto had not taken from the municipality away the opportunity to practically implement a form of territorial municipality guaranteed by the Constitution and that during this implementation, the municipality had not been legally dependent on the executive sector of the state power. A relative independence of municipal self-government lies in the fundamental separateness from the state executive.

A content of the parliamentary debate on a proposal of the act which has introduced a concept of legal regulation being reviewed by the Constitutional Court indicates a conflict of several legitimate interests. It concerns the interest to protect individuals against danger of gambling addiction which has serious wider social consequences (family break-ups, disruption of social system functionality and also high cost of eliminating consequences of gambling addiction), further it concerns protection of fundamental right to conduct business in case of gambling operators, since conducting business in this sphere is legal under the Slovak legal system. And last but not least, it concerns also a fiscal interest of public budgets, with respect to legal control of levies compulsorily paid by gambling operators (e.g. for years 2005 - 2011 it represents an income of the state budget in the amount of $643000000 €$ ).

In described circumstances the municipality with its right to selfgovernment has ended up rather at the edge of interest and has been put into a position of an imaginary lightning conductor through which the state is trying to earth a strong tension formed due to a conflict of described legitimate interests. Apparently it is a shame that municipality is legally liable for the way of solving this conflict of interests since law-making according to $\S 10$ par. 5 letter. $d$ ), belongs to a sphere of original competencies of the municipality performed at its own liability and at the same time its revenues from levies according to the Gambling Act are compared with revenues of the state rather marginal.

The legal regulation in question directly concerns the right of the municipality to self-government as one colliding value and only mediately the fundamental right to conduct business regarding gambling operators as another colliding interest protected by the Constitution. It logically arises from the character of the reviewed regulation which only introduces conditions for future normative restriction of the fundamental right to conduct business for bearers of public power other than the state.

individual form of this right has an absolute protection of the guarantee regarding the key content (decision from $7^{\text {th }}$ May 2001 in the matter ref. no. 2 BvK 1/00). 
Defining conditions for exercising of public power by a power holder other than the state, but accepted by the state is, in our opinion, necessary to regard as a legitimate reason for regulation activity of the legislator representing a primary bearer of public power, especially when a future exercise of public power by this other power entity shall directly attack fundamental rights and freedoms. Legal regulation regarding infringement of fundamental rights and freedoms and also other values protected by the Constitution belongs, in the first place, to the National Council as a directly legitimized representative of the state power. In a legal state a significance of fundamental rights and freedom as irremovable values not derived from the state is manifested inter alia in the fact that the legislator as a state body having the widest direct legitimacy is originally authorized to restrict the mentioned values. Therefore, this duty of the legislator is enforced in case when the legislator lawfully leaves restriction of fundamental right and freedom of general description to another, by the legislator acknowledged, legally independent entity, entitled to exercise the delegated part of the public power.

In the Gambling Act the state has decided that a normative control of gambling operation in the municipal territory shall be municipality's own competency. Thus the municipality has been allowed on its behalf and at its own liability to interfere with the fundamental right to conduct business regarding gambling operators. If the legislator who gave such competency to the municipality shall decide (again in a lawful way) to stipulate conditions for delegated restriction of the fundamental right to conduct business, it is not possible to object to it from a perspective of constitutionally significant legitimacy (comprising methodical part of the proportionality test).

Gambling represents a delicate issue of a legal regulation of social relations. On one side a legal business and on the other side a high risk of negative social impacts ${ }^{15}$. Thus a moral aspect of the analyzed type of business which in the Slovak legal system is represented by criteria of permissibility of business activity [§ 3 par. 3 of the Act no. 455/1991 Coll.

\footnotetext{
${ }^{15}$ The Court of Justice of the European Union (at that time European Court of Justice) in a decision from 24 $4^{\text {th }}$ March 1994 in the matter of Her Majesty's Customs and Excise v. Gerhart Schindler and Jörg Schindler (C-275/92) stated that with respect to all social aspects of gambling operations it is substantiated that bodies of member states have sufficient level of freedom in determining what is necessary for protection of gamblers and also generally, concerning specific social and cultural features of each member state, for keeping an order in the society, with regard to the way of operating lotteries, bet amounts and distribution of profit which they bring. Under these circumstances the member states must evaluate whether it is necessary to restrict lottery activities or even forbid them.
} 
on trade licensing (Trade Licensing Act) as amended by later regulations] emerges. Even though operation of gambling games is not a licensed trade, there is no doubt that such significant requirement regarding licensed trade as compliance of its performance with good manners, must show application overlap also to other types of business.

The Slovak legislator perceives gambling operations as a permissible type of business. It is such an important value attitude of the legislator that it must serve as a foundation for assessing appropriateness of a legal regulation in the Gambling Act. If a gambling operation is a legal business, legal profitmaking activity, the state mechanism may not deny them guarantees of a legal protection. Thus the reviewed legal regulation could be characterized as a manifestation of legitimate effort of the legislator to set frames for implementation of the municipality right to self-government in control of sensitive social relations on behalf of protection of the fundamental right to conduct business regarding gambling operators. Development of a legal regulation regarding position of the municipality within administration of gambling operations from implementation of $\S 10$ par. 5 letter d) of the Gambling Act is apparently a story of looking for a balance of both described interests.

Local character of the municipal self-government prefigures the approach to interpretation of Constitutional provisions which set norms on status of municipalities. The same conclusion applies also in relation to potential restrictions by which the legislator as a direct representative of a primary sovereign in the state limits a right of the municipality to self-government. If the legislator establishes a limitation which shall be based on the obligation of the municipality to require cooperation of the body of the state (even executive) power in exercising its right to self-government, it is necessary to consider such limitation substantially more strictly than a limit by which the legislator conditions application of a specific competency of the municipality upon activating another component of its right to a self-government (e.g. petition of the municipality population). In such case the legislator does not limit a right to self-government with a demand for cooperation of the entity legally different from the municipality (state or another statutory body), but rather on behalf of a deeper authenticity of implementation of the municipal self-government and on behalf of enforcing its legitimate foundation, which is in restricting of fundamental rights and freedoms a significant aspect. Of course, even in such situation we should not blunt an adequate alertness because variability of implied limitations may conceal a result leading to paralyzing of the municipal self-government. This could happen for example 
in the situation when application of one form of exercise of municipal selfgovernment which has legal binding consequences, would be conditioned upon another form, from an empiric perspective almost non-executable (e.g. local referendum with a required high participation quorum for purposes of achieving its validity).

In the Gambling Act the power of the municipal council as the municipal body is conditioned upon petition of $30 \%$ of the municipality population comprising its personnel substrate. The municipal council is the municipal body and municipality population represents its personal foundation. So the legal implementation procedure has two steps, however, both are reserved to entities or organization units which from a perspective of the right to selfgovernment comprise an integral part of the municipality. The municipal self-government at its essence and with its purpose leads to activating participants (municipality population) regarding administration of their own matters which unite the will of people living in the local community for purposes of fulfilment of public duties at their own liability (decision of the Federal Constitutional Court dated $12^{\text {th }}$ July 1960 on related matters ref. no. 2 BvR 373/60, 442/60).

In our opinion, thus the legal regulation of law-making power included in the Gambling Act does not exclude exercise of the right of the municipality to self-government in a form of normative restriction of gambling operations, only conditions its implementation upon manifestation of will of $30 \%$ municipality population, i.e. natural persons being a part of the local community, to whom the right to self-government as a collective right originally belongs and on behalf of whom municipality bodies should execute their own competencies. With regard to a constitutional core of municipal right to self-government this interference is evidently not sufficient for expressing violation of the municipal right to self-government. The challenged legal regulation concerns one concretized sphere of administration of municipal territory and within it only the issues regarding restriction of gambling operations either in all categories of buildings in which gambling rooms may be situated according to the Gambling Act or only in certain categories of such buildings. The respective municipality does not become in any way dependent on the will of other institutionalized bearer of the public power in deciding on limitation of gambling. Under these circumstances we may not state that essence of the municipal selfgovernment principle shall be emptied or that sufficient space for fulfilment of public duties of the municipality shall be taken away. The challenged legal regulation also does not deny the essence and purpose of the municipal 
self-government, because it does not obstruct the active approach of the municipality population to administration of their own matters.

\section{CONCLUSION}

Regulation of municipal self-government status in the Slovak Republic as well as legal regulation of its competencies went through a relatively dynamic development since 1990 (the Act on municipal establishment has been amended almost fifty times, not mentioning related acts regulating individual areas of public administration under which municipalities and self-government regions work). The point is to find an optimal status of the municipal self-government regarding the aspect of the state attitude towards it. We have to mention that during this process the state has made lot of mistakes. A typical example was a legal transfer of many competencies which originally belonged under liability of the state, to a sphere of municipal self-government liability, even before the adequate fiscal decentralization which should have provided sufficient financial resources so much needed for a quality performance of public power duties.

The role of the state in guaranteeing the status of municipal selfgovernment is irreplaceable. At the same time, it is a very demanding task for the power "mentality" of the state. The state itself should ensure a relevant share of public power performance on behalf of the entity other than itself in its own territory. However, handling of this role has a potential to bring the state positives in a form of developing micro-regions and municipalities as fundamental units of municipal self-government. It is not necessary to remind that so-called March Constitution representing a foundation for temporary act on municipalities which came from the idea according to which foundation of a free state is a free municipality (Průcha, 2012, s. 21 -23).

We may debate on quality as well as quantity aspects of competencies which should be performed by municipal self-government at its own liability and on its own behalf, for a long time. Without a doubt it is a coat which must be tailored to economic, social, geographic and demographic conditions of a particular state. However, the state may not be released of liability regarding two related areas. The first is setting of existence and mechanisms regarding activity of municipal self-government, the second is providing everyday functioning of such set system.

I dare to say that in the first area concentrated on making generally binding legal regulations the state has a lot of room for consideration. 
However, this may not be perceived as a basis for arbitrariness. In making use of this room the state must remember that the system of municipal selfgovernment which shall be set by the state itself in advance, must be later, at the implementation level, respected by the state itself. This naturally leads to the fact that in the second area of its assignment the state, through the bodies of implementation and application of the law, must honestly respect corridors stipulated by the constitution- makers and legislators under which the municipal self-government exists.

The presented article has focused on the second specified area. Thereby, it does not want to say that legal regulation of municipal self-government is flawless. Reality may even lie in the fact that the problems concerning generally binding legal regulation on status and activity of municipal selfgovernment may later form a pressure on implementation bodies in order to correct identified flaws with their power (often decisive) activity. However, the public power bodies representing the state must in the continental system withstand such pressure, which comes under the second concretized sphere of tasks. Judges do not have a legislative function. Their duty is only to discover sometimes, more sometimes less hidden connections of the legal regulation, to formulate principles on which the legal regulation of municipal self-government is built. Any correction of the legislator's will is interfering with a balance in three-division of the state power and last but not least, it damages a quality of judicial protection provided also to municipal selfgovernment. Low quality of the legal regulation may not be used here as an argument, because it is not unchangeable. There is no doubt that absence of thorough and in-depth municipal reform, high number of extremely small municipalities and associated incapability to fulfil public power duties on the required level but also deficiencies in regulating conditions of skilled performance of self-government competencies, create an environment which is very easily criticisable and at the same time applicable if we want to justify excessive application interferences with the right to self-government. However, a long-term preservation of the status quo casts over the state a shadow of suspicion that in reality a low quality performance of municipal self-government is convenient for it.

\section{REFERENCES}

BARAK, A. (2012). Proportionality. Constitutional rights and their limitations. Cambridge: Cambridge University Press, 2012. 
BEETHAM, D. (2009). Democracy: universality and diversity. In: Ethics \& Global Politics. Vol. 2, No. 4, 2009. pp. 281-296.

DRGONEC, J. (2015). Ústava Slovenskej republiky. Teória a prax. Bratislava: C. H. Beck, 2015.

FILIP, J. (1999). Ústavní právo. Základní pojmy a instituty. Ústavní základy ČR. $3^{\text {rd }}$ edition. Brno: Masarykova univerzita, 1999.

HOETZEL, J. (1937). Československé správní právo. Část všeobecná. $2^{\text {nd }}$ edition. Praha: Melantrich, 1937.

KOVAČ, P. (2015). Better Local Governance by Integrative Reorganization of State Administration and Self-Government (in Slovenia). In: The NISPAcee Journal of Public Administration and Policy. Vol. 7, No. 2, 2015, pp. 117134.

MITAL', O. (2018). The Impacts of Globalisation Processes on the Execution of Public Administration Functions. In: Political Sciences. Vol. 21, No. 4, 2018. pp. 96-117.

PRŮCHA, P. (2012). Správní právo - obecná část. $8^{\text {th }}$ edition. Plzeň: Vydavatelství a nakladatelství Aleš Čeněk, s. r. o. 2012.

VERNARSKÝ, M. - RUČINSKÁ, S. (2012). Nakladanie s majetkom ako samostatná pôsobnost' obcí v judikatúre slovenských súdov. In: Správní právo. Vol. XLIII, No. 7, 2012, pp. 410 - 425.

VERNARSKÝ, M. (2016). Uplatňovanie práva na samosprávu v aplikačnej praxi slovenských súdov. In: Metamorfózy práva ve střední Evropě V. Překrásný nový svět nebo ostrov?. Plzeň: Vydavatelství a nakladatelství Aleš Čeněk, 2016, pp. 244 - 260.

VYBÍHAL, V. (2018). Fiscal Decentralisation and Its Impact on Economy of Municipalities in the Slovak Republic and Czech Republic. In. Political Sciences. Vol. 21, No. 2, 2018. pp. 78-100.

ŽÁRSKA, E. (2013). Determinants of the Local Municipality's Status as an Actor of Development Processes. In: KLIMOVÁ, V. - ŽÍTEK, V. (eds.). 16th International Colloquium on Regional Sciences. Brno: Masarykova univerzita, 2013. pp. 352-357.

ŽOFČINOVÁ, V. (2018). Status of mayor of the municipality in branch of labour law. In: Právní rozpravy2018s podtitulem "Nové jevy a právo". Hradec Králove: Magnanimitas, 2018, pp. 256-262. 